\title{
Review on the Impact of World Higher Education Rankings: Institutional Competitive Competence and Institutional Competence
}

\author{
Zoljargal Dembereldorj ${ }^{1}$ \\ ${ }^{1}$ Center for Foreign languages, Division of Humanities, School of Arts and Sciences, National University of \\ Mongolia, Ikh surguuliin gudamj-1 P.O.Box - 46A/523, 210646, Ulaanbaatar, Mongolia \\ Correspondence: Zoljargal Dembereldorj, Center for Foreign languages, Division of Humanities, School of Arts and \\ Sciences, National University of Mongolia, Ikh surguuliin gudamj-1 P.O.Box - 46A/523, 210646, Ulaanbaatar, \\ Mongolia
}

Received: March 26, 2018

Accepted: April 20, 2018

Online Published: April 24, 2018

doi:10.5430/ijhe.v7n3p25

URL: https://doi.org/10.5430/ijhe.v7n3p25

\begin{abstract}
This paper discusses the relevant literature on higher education rankings and its impact on higher education institutions across the globe. The literature suggests that global university rankings impact higher education institutions both in advanced economy and developing countries to build competence to race and exist. Universities in an advanced economy are building institutional competitive competence to race in the global university rankings under the umbrella term of 'World Class University,' whereas universities in developing countries are building institutional competence by pursuing to build research intensive universities. The essay argues that global university rankings are shaping the field of higher education institutions, and the capacity of resources dictates universities the type of competence to build to exist: institutional competitive competence and institutional competence.
\end{abstract}

Keywords: university rankings, competence, higher education, impact, globalization

\section{Introduction}

The result release of the Global University Rankings (hereafter, GURs) has become one of the widely anticipated events of the academia around the world every year. Even though scholars of higher education have lamented the weakness of methodologies, GURs' impact is multidimensional, ranging from an individual level to national politics. Each party has its own interests on referring to the rankings of higher education institutions and, therefore, the ranking's influence is overarching (Hazelkorn, 2009).

Global University Rankings play a crucial role in designing national policies of higher education, in a broader spectrum, to build more advanced knowledge economy and in a narrower spectrum, to build competence in a higher education institution. GURs impact strategic plans of higher education institutions and their institutional policies. They assist academics and researchers to search for new international collaborations; they help prospective students and their parents to choose college and universities to study. Thus, GURs tend to serve as proxies for the choice, quality, performance and policy directions of higher education institutions in many countries (Salmi \& Saroyan, 2007; Clarke, 2007; Hazelkorn, 2009).

Many of the countries with advanced economy hold top-ranked higher education institutions in the GURs. Governments in these countries implement various policies which strengthen competence in their higher education institutions to compete with other top ranked higher education institutions, and maximize their reputation. For instance, Mok \& Chan (2008) documented that China and Taiwan have been implementing policies to position their universities higher in the GURs. Global University Rankings have influenced China and Taiwan to build more competitive research universities on the global arena.

With the rise of global university rankings, Europe has begun to modernize its higher education (Hazelkorn \& Ryan, 2013). "In response to the growing interest in global rankings, higher education and university-based research have become central to EU policymaking in a dramatic and significant way" (Hazelkorn \& Ryan, 2013, p. 83). For instance, Baker \& Lenhardt (2008) and Mohrman et al., (2008) documented emerging new model for a German research university. "Emerging Global Model universities are characterized by an intensity of research that far exceeds past experience and they are engaged in worldwide competition for students, faculty, staff, and funding; they operate in an environment in which traditional political, linguistic, and access boundaries are increasingly porous" 
(Mohrman et al., 2008, p.6). GURs serve as an alarm for higher education institutions to change and modernize in response to the ever-strengthening knowledge economy and growing globalization across the continents. Hence, national level policies in response to the GURs for countries with advanced economy tend to aim at building or strengthening a 'world class university.'

At an institutional level, especially, in Asia, internationalization has become one way of building the institutional competitive competence to maximize the institutional reputation and position in GURs well. For instance, South Korean higher education institutions have begun to implement English mediated instructions to boost its internationalization. Byun et.al. (2011) documented that one reason of implementing English medium instruction policies at Korean higher education institutions was to boost internationalization by attracting foreign students and scholars. This policy is one way of increasing the higher education competiveness on the global arena, as internationalization is one of the indicators of GURs. Thakur (2007) documented that one of the prestigious universities in Malaysia had dropped 80 places in the Times Higher Education Ranking which led to replace its Vice-Chancelor; it implied the challenges posed in the governance and the management of the university.

At an individual level, the importance of ranking and its effects is espoused by the fact that GURs help students and their parents make choices to which college or university to go. For example, a study on the effects of annual US News and World Report Guide to America's Best Colleges on high school graduates (Griffith \& Rask, 2007) found that school choice was responsive to changes in rank, and rankings was also important for women, minorities, and the highest ability students. University rankings help students make their choice for the college, and it has called higher education institutions to be changed, modernized, and globalized. The influence of university ranking is overarching ranging from national to individual level and therefore, university ranking is multifaceted and serves different purposes for policymakers, higher education institutions, students and parents.

GURs is particularly important for higher education institutions and national policies as ranking provides them with information how to "fairly" compete in a global arena and raise their reputation. In response to GURs, world higher education systems have been changing and everyone does what they are able - some are making organizational changes, some are making policy changes, some are encouraging higher education institutions with financial incentives from government or business organizations and some are internationalizing its campus with international students and English medium instructions. These initiatives of modernization in higher education system are seen to be taking place in more economically advanced societies where higher education institutions are ranked at least within top five hundreds of the GURs. Thus, GURs matter much for higher education institutions of advanced economy to "race" in the GURs. That is, advanced economies attempt to build competitive institutional competence in their higher education institutions in order to maximize global rankings status.

One of the manifestations to build competitive institutional competence is to build world class universities. As Marginson (2010) rightly mentioned that most league tables are limited to a top 200 or 500 institutions, and those lists of top 200 or 500 serve as definition of "world class universities." Naturally, all universities in the developed world are willing to maximize their rank within that category, and all emerging nations, and all leading research universities within those nations, want to be part of the category "world class" and to rise as high as possible within it (Marginson, 2010).

On the other hand, it is not clear if Global University Rankings matter for newly developing economies where their higher education institutions are far away to be ranked within the top five hundreds. Unfortunately, very little is known about how GURs are shaping higher education institutions of those which are not ranked within the top 400 hundreds of the GURs (for example, as of 2013 Times Higher Education World University Ranking) and those which are located in developing economies. Hence, it urges the need of study on GURs with regard to low ranked higher education institutions embedded with its newly developing economies.

It is important to study the effects of GURs on higher education institutes in a context of a developing economy where its higher education institutions can hardly be found within rankings news. One of the worldwide popular university ranking systems, the Times Higher Education announces world top four hundreds universities every year. Academic Rankings of world universities by Shanghai Jiao Tong University announces world top five hundreds universities annually. Higher education institutions ranked within these numbers are building competitive competence with strategies to maximize their status and reputation in a global arena. On the other hand, higher education institutions in a newly developing economy can be assumed that they fall short to build competitive institutional competence to race with those already ranked in the top five hundred due to their limited resources. Hence, the impact of GURs can be different on higher education institutions of developing countries due to the lack 
of resources to build world class universities; and their response to GURs is to imitate other "successful" research universities rather than compete to build a "world class university."

To understand the impact of the world higher education rankings, the paper sheds light on its meaning and history. It can provide us with background of higher education rankings and its impacts to change world higher education institutions.

\section{What is a University Ranking?}

We begin to review the relevant literature by asking how the ranking of higher education institutions is defined. There is limited paper on how we can define ranking of higher education institutions conceptually. However, few recent literatures can help us to understand what it is.

Shin (2011) views university rankings as a measure of organizational effectiveness. We can identify three mechanisms for quality measurements of higher education institutions: ranking, quality assurance and accountability (p.25). Although these three mechanisms have been much in common because they provide information to the public and enhance institutional quality, they differ in their goals, methods of evaluation, publishing of results, and the policy links (Shin, 2011, p.25).

On the other hand, Usher and Savino (2006; 2007) and Usher and Medow (2009) defined that "university rankings are lists of certain groupings of institutions (usually, but not always, within a single national jurisdiction), comparatively ranked according to a common set of indicators in descending order" (p.4). They added that rankings also serve for public as information of their expenditure on education and help parents and students to make decision which college to go. Taken together and drawing from both definitions, we can understand that university ranking is information with scales of items ordered in rank based on individual institutional quality and serves for laymen and professionals as information.

The rankings have also considered as a comparison of higher education institutions, especially research oriented universities. Rankings compare countries, individual universities, and fields of study, such as management and business administration (Altbach, Reisberg \& Rumbley, 2009). Comparisons among institutions might stimulate those who not fair so well to become better and thus the whole system might improve - if the indicators set the right incentives (Federkeil, 2008). Worldwide rankings norm higher education as a single global market of essentially similar institutions able to be arranged in a league table for comparative purposes (Marginson \& van der Wende, 2007). It has been also defined as quality assurance measurements by being an external assessment for higher education institutions. Federkeil (2008) defined rankings and league tables to be external assessment of higher education quality by nurturing transparency of the higher education system.

\section{The Practice of University Ranking}

It is documented that the first ranking of higher education institutions was introduced in the United States (Myers \& Robe, 2009; Shin \& Toutkoushian, 2011; Usher\& Savino, 2007). Myer \& Robe documented that there have been two major periods in which each method of ranking was ascendant: outcomes-based rankings, derived from studies of eminent graduates, were published in great number from 1910 to the 1950s, while reputational rankings became the norm starting in 1958 and continuing to the present.

We will briefly elaborate historical development of rankings as Myer \& Robe (2009) have studied. The first ranking of higher education institutions is published by an Englishman, Alick Maclean in 1900. At the end of his book entitled "Where We Get Our Best Men," the author ranked universities in order by absolute number of eminent men who had attended them. Later in 1910, American psychologist, James McKeen Cattell published "American Man of Science" listed American colleges in order of weighted ratio of eminent scientists' attendance and teaching intuitions. This served as a basis for future American university rankings.

Reputational rankings resembling our contemporary GURs would become popular in the beginning in 1959 to assess the academic quality. It began to run by U.S. News and World Report with strong components of reputational evaluation. Usher \& Savino (2007) documented that they were originally created in order to meet a perceived market need for more transparent, comparative data about educational institutions.

The ranking methodology was developed earlier in 1924 by Raymond Hughes (Myer \& Robe, 2009; Shin \& Toutkoushian, 2011). Early rankings used several "dimensions of quality," inter alia, faculty expertise, graduate success in later life, and academic resources such as faculty/student ratio or volumes in the library, while later formats have relied more on reputational indicators, using Science Citation Index, 1961 and annually thereafter, and the Social Science Citation Index, 1966 and then yearly (Hazelkorn, 2011, p. 498.) 
During the beginning period of reputational rankings in the United States, they tended to focus more on graduate-level programs. Later in 1983, U.S. News and World Report published first undergraduate reputational ranking. Following the example of the US News ranking, a growing number of commercial media and research institutions have begun to release ranking worldwide and/or nationally (Shin \& Toutkoushian, 2011).

Based on the university ranking system, that of US News and World Report, global university rankings rose with Academic Research University Ranking in 2003 and Times Higher Education in 2004. Hazelkorn (2011, p. 499) called it as the third era of university ranking - Global University Rankings. Even though there are other rankings have mushroomed around the world, aforementioned two ranking systems are the most attractive for students, parents, academics, higher education institutions and scholars of higher education studies. Hence, growing body of literature on GURs focused on the above two ranking systems.

\section{Globalization, Knowledge Economy and University Rankings}

GURs is particularly important for higher education institutions and national policies as ranking provides them with information how to "fairly" compete in a global arena and raise their reputation. In response to GURs, world higher education systems have been changing and everyone does what they are able - some are making organizational changes, some are making policy changes, some are encouraging higher education institutions with financial incentives from government or business organizations and some are internationalizing its campus with international students and English medium instructions. These initiatives of modernization in higher education system are seen to be taking place in more economically advanced societies where higher education institutions are ranked at least within top five hundreds of the GURs. Thus, GURs matter much for higher education institutions of advanced economy to "race" in the GURs. That is, advanced economies attempt to build competitive institutional competence in their higher education institutions in order to maximize global rankings status.

Kozminski (2002) is one of the advocates of global university rankings. The author stressed that globalization is an endless process of adjustment (Kozminski, 2002) which implied that higher education institutions should also be adapted to a global society. The reason is that locally oriented higher education institutions wind up to be very local, while globalized higher education institutions wind up to be imitating top-class international higher education institutions. It is important to find a balance of how much to be local and how much to be international. Hence, the rankings of higher education institutions should reflect a healthy balance between universal global values and local characteristics of cultures, societies, and educational system (Kozminski, 2002). The author continued that it will bring the excellence in higher education.

The excellence can be fostered by emerging new landscape of higher education, the Global University Rankings. It creates the higher education landscape - a "relational landscape," where institutions and nations are constantly measured against each other according to indicators of global capacity in which comparative and competitive advantages come into play (Hazelkorn, 2011, p.14). GURs creates the new relational landscape of excellence characterized by research and scholarly excellence. The excellence tends to be perceived by the GURs based on research and its outputs. Because knowledge is created from the research, research activities and its output is the center of the excellence of higher education.

University rankings are cultivating globalization and knowledge economy and within them, the competiveness of higher education institutions. Hazelkorn (2013) advocated that first, university rankings are simple and easy comparison of education production and performance; second, they have become a major tool for measuring educational quality and excellence; and third they indicate the global competitiveness. They are simple because they compare higher education institutions with a single digit aggregated from different indicators. Even though they treat all higher education institutions same in their indicators, there is no global consensus of education quality. Moreover, they can help maintain and build institutional position and reputation, good students use rankings to "shortlist" university choice, especially at the postgraduate level, and stakeholders use rankings to influence their own decisions about funding, sponsorship and employee recruitment (Hazelkorn, 2013).

Some argued that university rankings are fostered by knowledge economy, capitalism, and openness of knowledge, but some implied that they are fostering global competiveness of higher education institutions. We can see that it can also be vice versa and interchangeably fostering one another. It can also be considered as the praise for university rankings in way that they play a crucial role for building capacity in human capital. Dill (2009) emphasized the importance of human capital function of universities in contemporary world of globalization. The development of the nations depends on their ability to efficiently cultivate their stock of human talent through their educational systems (Dill, 2009). The global rankings influence positively that nations around the globe aspire to reform their policies to increase their reputation in terms of higher education. They also influence to increase the research activities, 
quality and investment into research and development. "To the extent that world university league tables provide a general indicator, somewhat like indicators of world health or education, that help motivate systemic policy analyses of the strengths and weaknesses of existing university systems, rankings can perform a useful canary-like warning function" (Dill, 2009). The author also suggested that there is a need to improve the university rankings.

\section{Controversies around Global University Rankings}

Since the release of Global University Rankings - Times Higher Education and Academic Rankings of World Universities, these rankings have begun to draw much attention by scholars and researched extensively. Taylor and Braddock (2007) examined two well-known global rankings: Times Higher Education Supplement and Academic Rankings of World Universities, and assessed their criteria. They found that Times Higher Education Supplement had strong regional bias as the peer reviewers are merely asked within their own region (Taylor \& Braddock, 2007). On the contrary, they found Academic Rankings of World Universities is freer from subjectivity and per capita productivity indicates consistent research involvement (Taylor \& Braddock, 2007). Moreover, Ioannidis et al., (2007) compared the two rankings and assessed the construct validity for educational and research excellence, and their measurement. They found both had no construct validity for educational and research excellence in terms of adjustment for institutional size, definition of institutions, implications of average measurements of excellence versus measurements of extremes, adjustments for scientific field, time frame of measurement and allocation of credit for excellence (Ioannidis et al., 2007). In the same vein, Soh (2013) argued "university ranking has to be raised to a level of more rigorous scientific research and not to stay at the level of sensationalised surveys" (p. 213)." The reason is the discrepancy between nominal and attained weights which can mislead the consumers (Soh, 2013).

Critiques of rankings usually center on its methodology. Buela-Casal, Gutierrez-Martinez, Bermudez-Sanchez \& Vadillo-Munoz, (2007) compared four global university rankings and found that all four selected international rankings include some indicator within the category "quality of research." There was much weight on reputational surveys, whereas there were no measures of learning process. In addition research performance, Chen \& Liao (2012) compared inter-correlation between rankings of Academic Rankings of World Universities, World University Ranking and Performance Ranking of Scientific Papers for World Universities and intra-correlation within rankings and respective bibliometric indicators. They also compared correlation of indicators within them. They found strong correlation of indicators between Academic Rankings of World Universities and Performance Ranking of Scientific Papers for World Universities; and strong significant correlation rankings and bibliometric indicators. These studies imply that university rankings do not necessarily reflect teaching or teaching quality.

Another study compared Times Higher Education and Academic Rankings of World Universities. With regression analysis, they tested hidden factors - language, country, size, age, scope and focus, and reputation. It found rankings have different conceptions of university quality and the existence of an underlying entity profile, characterized by institutions with a high reputation, from the U.S. or other English-speaking countries, oriented towards research that is active in hard sciences, and have extensive budgets (Safon, 2013). The most robust factors were reputation and location of US. Hence, it argues rankings is fostering so called "Matthew effect." With the support of this argument, Hazelkorn (2008) claimed that the Matthew Effect will become increasingly obvious, as higher education is arguably restructured for the benefit of elite high-achieving students and their institutions. The author continued that it is very harmful for newly developing countries, their higher education institutions and newly established higher education institutions.

Global University Rankings - Times Higher Education and Academic Rankings of World Universities are the most prominent and highly referenced rankings and they were criticized much by scholars. Billaut, Bouyssou, \& Vincke (2009) examined Academic Rankings of World Universities with its six criteria through Multiple Criteria Decision Making. They found that each of the criteria is only loosely connected with what should be captured and therefore, their evaluation involves the use of arbitrary parameters and arbitrary micro-decisions (Billaut Bouyssou, \& Vincke, 2009). Two criteria for Noble prize and field medals were covered with much problem of bias (e.g., Einstein Nobel Prize case) and they do not cover all important scientific fields. Criterion for high citation was revealed to be not the representative indicator of the present ability of institution production. For the papers in nature and science, first, author's affiliation does not reflect precisely, second the Thomson Scientific database could not fully represent, third, papers are skewed towards English and fourth, they calculate indexed papers but not the impact of the paper (Billaut, Bouyssou \& Vincke 2009). Final criteria of productivity were led by the impreciseness of the above criteria. Hence, they concluded that criteria were random and depended on availability. In spite of the many criticisms that the Shanghai's rankings have attracted, if Academic Rankings of World Universities is taken at face value, i.e. as a reasonable tool to measure the research quality of a university through some carefully selected indicators related to 
the quantity and quality of its scientific production and the excellence of its students and alumni, the information it provides, when properly used, allows us to gain a useful insight into the research performance of whole university systems (Docampo, 2010).

Bookstein, Seidler, Fieder, \& Winckler (2010) conducted a simple statistical analysis Times Higher Education (Note 1) validity. Main components - peer review, employer review and citation per faculty member- assessed in Pareto distribution. They found that year to year results were unreliable and valid. Many year-on-year changes in the "peer rankings" of the five faculty subdivisions show unacceptable instability of variance from year to year (Bookstein, Seidler, Fieder, \& Winckler, 2010). Variance was .048 in 2007, whereas .104 in 2008. It is unclear by what algorithm a variable number of mentions in an unordered list is converted into a summary "peer ranking," nor what is a rational behavior for the reader who might wish to know when to stop listing universities (Bookstein, Seidler, Fieder, \& Winckler, 2010). Whether or not colleges and universities agree with the various ranking systems and league table findings is irrelevant, ranking systems are clearly here to stay (Merisotis, 2002).

Salmi and Saroyan (2007) examined league tables with their similarities and their potential to be used as information for policymakers and students. They observed that league tables, first, include indicators as proxies for quality; second, weighted score is accorded to each set or cluster of indicators; third, there is little consideration of differences of institutions; fourth, they compare institutions as the unit; fifth, they rely on peer review data (Salmi \& Sayoran, 2007). They conclude that even though these characteristics share similar approaches to institutional measurement of quality and performance, they do not necessarily measure quality of higher education institutions. However, measurement of quality is left with questions.

There are two controversial issues on convergence and divergence of quality in relation to university rankings. Dill and Soo (2005) compared five commercial rankings: The Good Universities Guide (Australia); The Maclean's Guide to Canadian Universities; The Times Good University Guide (UK); The Guardian University Guide (UK); and US News \& World Report, America's Best Colleges. They used criteria for evaluating organizational report cards which include validity, comprehensiveness of the measures, relevance and comprehensibility of information, and functionality of the rankings. They argued that the review of the five leading commercial university league tables from Australia, Canada, the UK, and the US suggests that the definitions of academic quality used in these tables are converging.

In contrast to convergence, Usher and Savino $(2006,2007)$ revealed the divergence of quality measurement of university rankings. The study examined 19 university league tables across the world and concluded that there is no convergence in quality measurement of university ranking. The reason is first, vast differences exist between university league tables in terms of what they measure, how they measure it and how they implicitly define "quality" and second, some of these differences appear to be geographic or cultural in nature (Usher \& Savino 2006, 2007). They identified that the problem lies in the fact that the university rankings approach to "one-size-fits-all" (Usher \& Savino 2006, 2007).

\section{University Rankings and the Pursuit of the World Class Universities}

GURs has brought about numerous impacts around the world. First, it has begun to serve as a major dynamics of higher education around the world. Marginson (2006) discussed Global University Rankings as a dynamic for higher education which is creating global hierarchy of higher education institutions and nations. The global hierarchy is structured by three factors: distribution of research activity, global advantage of English and global dominance of US higher education (Marginson, 2006). GURs as a dynamic to reform world higher education institutions has two main reforms: economically advanced countries such as Japan, China, Taiwan, South Korea, Australia, Germany, France have committed to build "world class universities;" whereas economically less advanced or countries without research universities have committed to build research oriented universities. I begin to review the literature of "world class universities" to examine the impacts of GURs as a dynamic for changes in higher education systems around the world.

"World class university" has emerged as a notion with regard to GURs. Growing number of literature have discussed world class as one of the crucial impact of the GURs. Van Vught (2008) explored that the higher education institutions are racing for the reputation and prestige. One of the dynamics of the 'reputation race' (Van Vught, 2008) is the university rankings that accelerate the competition among higher education institutions. Their reputation is characterized by attracting talented students, scholars and research resources. The behavior of higher education institutions is triggered by the condition of another market, that of competition for institutional reputation (Van Vught, 2008). It implies that the reputation is obtained by the "world-classness" if a higher education institution is 
ranked at the top of GURs. Since, reputation is foremost important for higher education institutions, the most vivid impact is building a world-class university.

Many studies suggest that governments attempt to build so-called a "world class university" as a response to GURs. Mok and Chan (2008) examined the national responses and policies in higher education of China and Taiwan. They base these responses and policies as an impact of GURs which leads both countries to pursue "world class university" initiatives. China and Taiwan approached pragmatically to build a "world class university' for benchmarking with global top universities. These pragmatic approaches were resource concentration on few selective higher education institutions and strategies for internationalizing the campus. GURs impacts on government policies to enhance competition among higher educations through funding while they impact on higher educations in China and Taiwan to increase exchange students with other countries and cooperate with institutions abroad.

In the same vein, Yonezawa (2011) examined the Japanese response to GURs. As one its world class pursuit, Japanese government prioritized internationalization of higher education. The Fukuda Cabinet (2007-2008) the government set up a plan to invite 300,000 international students by 2020 , which meant that the country would aim to triple the existing number of international students within only 12 years and this plan targeted the selection of 30 national, local public and private universities for internationalization, the "Global 30" (Yonezawa, 2011). The author concluded that there is much difference in context of countries to pursue a "world class university" as compared to China and South Korea.

Moreover, Byun et. al., (2012) explained world class university policies in South Korea through the lens of Salmi's world class university concept. According to Salmi, a "world class university" entails concentration of talent, abundance of resource and favorable governance (Salmi, 2009). Through this lens, South Korean case has been examined. The government has implemented three policies to build a world class university: Brain Korea 21 or BK21, World Class University project and Study Korea project. Brain Korea 21 is to enhance research activities, World Class University is designed to import prominent scholars and Study Korea project is to recruit international students. They produced more favorable conditions for Korean universities to become World Class Universities (Byun et. al., 2012), but there were other consequences for the pursuit of "world class university." While the World Class University policies in Korea appear to be successful in upgrading a few institutions to almost world-class quality, they simultaneously risk encouraging unbalanced development, low quality, and the Westernization of education and scholarship (Byun et., al, 2012).

In Singapore, Xavier and Alsagoff (2013) argued the National University of Singapore is pursuing "world-class" as being "global." The National University of Singapore is using a strategy of international alliance by holding cooperation and official relations with top universities abroad; research achievements by emphasizing areas of medicine, technology, science and engineering; and developing global students by emphasizing exchange programs in other universities (Xavier \& Alsagoff, 2013). The authors viewed these strategies not much finding the balance between local needs and global aspirations.

Countries with advanced economies are pursuing a "world class university" to race up to the top of the GURs and enhance their reputation. GURs impacts on higher education institutions in advanced economies in way that they have to become one of the world class universities by internationalization or research escalations which needs wealth of resources. From the literature, we can see that GURs impacts are relative on higher education systems in countries. Advanced economies race their higher education institutions for the country's image, reputation and economic benefits. Hence, they are building competitive institutional competence to improve their status and reputation in the GURs.

The notion of building a "world class university" is perceived to be competitive competence building in higher education institutions to increase the performance especially in research capability and human resource. For instance, Liu (2011, p.,65) discusses how China is striving to build a world class university with its government increasing financial support. In the same vein, government of South Korea has been implementing policies to encourage research activities and internationalization (Byun et al., 2012) while Japanese government is focusing more on internationalization of its key higher education institutions to attract talented international students (Yozenawa, 2011). In Taiwan, the Ministry of Education and the National Science Council have jointly launched the "Programme for Promoting Academic Excellence of Universities," primarily aiming at improving universities' infrastructure and invigorating research (MOE Taiwan, 2000 cited from Deem et al., 2008). Thus, building a "world class university" can be considered to build competitive institutional competence to maximize the reputation and status in GURs. 
There is a question of less economically advanced and newly developing countries on how they manage to respond to the changing environment of "positional markets" (Marginson, 2006). Higher education institutions with lack of resources face challenges to afford expensive research facilities and resources and build world class universities. In much of the world, especially in developing countries, policymakers engaged almost exclusively with meeting mass higher education demand, largely ignoring the research role of universities (Altbach, 2007, p. 3). Then how can developing countries afford building a "world class university?" Will they pursue world classness with limited resource, talented scholars, students and internationalize the university? It is very doubtful for developing country to reckon to race without any "equipment." However, they can respond to the GURs within its "boundary" because higher education institutions in developing countries should be considered to serve the country's economic development and higher education institutions cannot survive if they do not reform themselves. Newer research universities struggle hard to break into the upper echelon, imitating its programs and ethos, but in a status market late-comers are locked out (Marginson, 2006). Schwartzman (2007) argued that the importance of world class universities does not relate only to the need to participate and compete internationally in the areas of advanced science and technology. Hence, higher education institutions in developing countries will imitate the model of American research universities to build a research university to respond to the changing environment of higher education rather than pursuing "world classness."

\section{Strategies in Response to Changing Environment of World Higher Education}

Higher education institutions have been changing and taking actions in response to the GURs. Hazelkorn (2009) identified changing actions in research, changes in organizational structure, curriculum that bridges EU and US model, target Ph.D students and internationalization, hire talented scholars and changes in management and marketing of higher education institutions (Hazelkorn, 2009). The author continued to explain that higher education institution leaders are very much concerned about the GURs and response actively by making institutional level changes in an European context. These responses were institutional strategy such as developing new plan for reform, organizational such as reorganizing the departments, management such as developing budgetary tools for supporting excellence of research and academic such as more demand for individual faculty member's research productivity (Hazekorn, 2008).

In the same vein, Kim and Nam (2007) discussed the institutional responses to GURs in South Korea. They explained how Seoul National University had been changing and upgrading the university. Seoul National University shifted their doctoral program requirements with more comprehensive examination and graduate course similar to US system. The university began to encourage faculty members to publish articles in internationally acclaimed journals for the consideration of new hires as well as the tenure review process (Kim \& Nam, 2007). The university began to promote more global connection through faculty and joint degrees with foreign higher education institutions. They identified that such changes and reform policies are improving the overall institutional performance. Arimoto (2011) also identified that South Korea has placed the first (average research productivity was 36.0) in their research productivity in comparison with Japan, Italy, China, Germany and so on.

As GURs are holding research performance at its heart, there is a study which documents research and internationalization are the main response. Horta (2009) found that internationalization of research universities' student population and academic staff is related to enhance research quality in European two universities. The author further concluded that government can be the engine for internationalization and only the state can provide the financial resources for a country to build or maintain a competitive "world class university" in the global arena (Horta, 2009). Overall, the above mentioned studies imply that there is a strong commitment to change higher education institutions globally.

Drawing from the above literature, the review concludes that there still remains the gap in the literature on how higher education institutions in a developing country are building institutional competence to survive in a changing field of higher education. As Altbach (2007) postulated that developing countries need research universities but their goals will be different than those in advanced economies. That is, higher education institutions in a developing countries will be fostering to imitate those top ranked ones than race to the top. While there exists pressure of the changing higher education environment, the pressure of resources to build competence exists at the same time. Thus, world higher education institutions are purported to build two types of competence: institutional competitive competence for top ranked universities and institutional competence for universities in developing countries. 


\section{References}

Altbach, P. G. (2007). Empires of Knowledge and Development. In Altbach, P. G., \& Balán, J. (Eds.). World class worldwide: Transforming research universities in Asia and Latin America. JHU Press.

Arimoto, A. (2011). Reaction to Academic Ranking: Knowledge Production, Faculty Productivity from an International Perspective. In Shin, Toutkoushian and Teichler eds. University Rankings: Theoretical basis, methodology and impacts on global higher education. Springer.

Baker, D. P., \& Lenhardt, G. (2008). The institutional crisis of the German research university. Higher Education Policy, 21(1), 49-64. https://doi.org/10.1057/palgrave.hep.8300178

Billaut, J.-C., Bouyssou, D., \& Vincke, P. (2009). Should you believe in the Shanghai ranking? Scientometrics, 84(1), 237-263. https://doi.org/10.1007/s11192-009-0115-x

Bookstein, F. L., Seidler, H., Fieder, M., \& Winckler, G. (2010). Too much noise in the Times Higher Education rankings. Scientometrics, 85(1), 295-299. https://doi.org/10.1007/s11192-010-0189-5

Buela-Casal, G., Gutiérrez-Martínez, O., Bermúdez-Sánchez, M. P., \& Vadillo-Muñoz, O. (2007). Comparative study of international academic rankings of universities. Scientometrics, 71(3), 349-365. https://doi.org/10.1007/s11192-007-1653-8

Byun, K., Chu, H., Kim, M., Park, I., Kim, S., \& Jung, J. (2011). English-medium teaching in Korean higher education: Policy debates and reality. Higher Education, 62(4), 431-449. https://doi.org/10.1007/s10734-010-9397-4

Byun, K., Jon, J.-E., \& Kim, D. (2012). Quest for building world-class universities in South Korea: outcomes and consequences. Higher Education, 65(5), 645-659. https://doi.org/10.1007/s10734-012-9568-6

Chen, K.-h., \& Liao, P.-y. (2012). A comparative study on world university rankings: a bibliometric survey. Scientometrics, 92(1), 89-103. https://doi.org/10.1007/s11192-012-0724-7

Clarke, M. (2007). The impact of higher education rankings on student access, choice, and opportunity. Higher Education in Europe, 32(1), 59-70. https://doi.org/10.1080/03797720701618880

Deem, R., Mok, K. H., \& Lucas, L. (2008). Transforming Higher Education in Whose Image? Exploring the Concept of the "World-Class" University in Europe and Asia. Higher Education Policy, 21(1), 83-97. https://doi.org/10.1057/palgrave.hep.8300179

Dill, D. D. (2009). Convergence and Diversity:The Role and Influence of University Rankings In B. M. S. Kehm, Bjørn (Ed.), University Rankings, Diversity, and the New Landscape of Higher Education (pp. 97-116). Rotterdam: Sense Publisher.

Dill, D. D., \& Soo, M. (2005). Academic quality, league tables, and public policy: A cross-national analysis of university ranking systems. Higher Education, 49(4), 495-533. https://doi.org/10.1007/s10734-004-1746-8

Docampo, D. (2010). On using the Shanghai ranking to assess the research performance of university systems. Scientometrics, 86(1), 77-92. https://doi.org/10.1007/s11192-010-0280-y

Federkeil, G. (2008). Rankings and quality assurance in higher education.Higher Education in Europe, 33(2-3), 219-231. https://doi.org/10.1080/03797720802254023

Griffith, A., \& Rask, K. (2007). The influence of the US News and World Report collegiate rankings on the matriculation decision of high-ability students: 1995-2004. Economics of Education Review, 26(2), 244-255. https://doi.org/10.1016/j.econedurev.2005.11.002

Hazelkorn, E. (2008). Learning to Live with League Tables and Ranking: The Experience of Institutional Leaders. Higher Education Policy, 21(2), 193-215. https://doi.org/10.1057/hep.2008.1

Hazelkorn, E. (2009). Rankings and the battle for world-class excellence. Higher education management and Policy, 21(1), 1-22. https://doi.org/10.1787/hemp-v21-art4-en

Hazelkorn, E. (2011) Rankings and the Reshaping of Higher Education: The Battle for World Class Excellence. Houndmills, Basingstoke: Palgrave Macmillan. https://doi.org/10.1057/9780230306394

Hazelkorn, E. (2013). How Rankings are Reshaping Higher Education. In V. Climent, Michavila, F. and Ripolles, M. (Ed.), Los Rankings Univeritarios: Mitos y Realidades. Tecnos. 
Hazelkorn, E. \& Ryan, M. (2013). The Impact of University Rankings on Higher Education Policy in Europe: a Challenge to Perceived Wisdom and a Stimulus for Change. In P. Zgaga, U. Teichler \& J. Brennan (Eds, The Globalization Challenge for European Higher Education: Convergence and Diversity, Centres and Peripheries. Frankfurt, Peter Lang.

Horta, H. (2009). Global and national prominent universities: Internationalization, competitiveness and the role of the state. Higher Education, 58(3), 387-405. https://doi.org/10.1007/s10734-009-9201-5

Ioannidis, J. P., Patsopoulos, N. A., Kavvoura, F. K., Tatsioni, A., Evangelou, E., Kouri, I., . . Liberopoulos, G. (2007). International ranking systems for universities and institutions: a critical appraisal. BMC Med, 5, 30. https://doi.org/10.1186/1741-7015-5-30

Kehm, B. M., \& Stensaker, B. (2009). University rankings, diversity, and the new landscape of higher education. Rotterdam: Sense Publishers.

Kim, K.-S., \& Nam, S. (2007). The making of a world-class university in the periphery: Seoul National University. In P. G. Altbach \& J. Balán (Eds.), World class worldwide: Transforming research universities in Asia and Latin America (pp. 122-142). Baltimore: The Johns Hopkins University Press.

Kozminski, A. (2002). The role of Higher Education in Societies in transition within the Globalized environment: Solid Academic Credentials and hte challenges of buiding up an institutional image. Higher Education in Europe, 27(4), 365-371.

Liu, N. C. W., Qi \& Cheng, Ying. (2011). Paths to a World-Class University Lessons from Practices and Experiences. The Netherlands: Sense Publishers.

Marginson, S. (2006). Dynamics of national and global competition in higher education. Higher education, 52(1), 1-39. https://doi.org/10.1007/s10734-004-7649-x

Marginson, S. (2008). Global field and global imagining: Bourdieu and worldwide higher education. British Journal of Sociology of Education, 29(3), 303-315. https://doi.org/10.1080/01425690801966386

Marginson, S. (2010). Global comparisons and the university knowledge economy. In Higher education, policy, and the global competition phenomenon (pp. 29-41). Palgrave Macmillan US. https://doi.org/10.1057/9780230106130_3

Marginson, S., \& van der Wende, M. (2007). To Rank or To Be Ranked: The Impact of Global Rankings in Higher Education. Journal of Studies in International Education, 11(3-4), 306-329. https://doi.org/10.1177/1028315307303544

Merisotis, J. P. (2002). On the rankings of Higher Education Institutions. Higher Education in Europe, 27(4). https://doi.org/10.1080/0379772022000071832

Mohrman, K., Ma, W., \& Baker, D. (2008). The research university in transition: The emerging global model. Higher education policy, 21(1), 5-27. https://doi.org/10.1057/palgrave.hep.8300175

Mok, K. H., \& Chan, Y. (2008). International Benchmarking with the Best Universities: Policy and Practice in Mainland China and Taiwan. Higher Education Policy, 21(4), 469-486. https://doi.org/10.1057/hep.2008.21

Myers, L., \& Robe, J. (2009). College rankings: History, Critisism and Reform.: Center for College Affordability and Productivity.

Safón, V. (2013). What do GURs really measure? The search for the X factor and the X entity. Scientometrics. https://doi.org/10.1007/s11192-013-0986-8

Salmi, J., \& Saroyan, A. (2007). League tables as policy instruments. Higher education management and policy, 19(2), 1-38. https://doi.org/10.1787/hemp-v19-art10-en

Schwartzman, S. (2008). University and development in Latin America. Rotterdam: Sense.

Shin, J. C. (2011). Organizational effectiveness and university rankings. In J.C. Shin, R.K. Toutkoushian \& U. Teichler (Eds), University Rankings (pp. 19-34). Springer Netherlands. https://doi.org/10.1007/978-94-007-1116-7_2

Shin, J. C., \& Toutkoushian, R. K. (2011). The past, present, and future of university rankings. In University Rankings (pp. 1-16). Springer Netherlands. https://doi.org/10.1007/978-94-007-1116-7_1 
Soh, K. (2013). Misleading university rankings: Cause and cure for discrepancies between nominal and attained weights. Journal of Higher Education Policy and Management, 35(2), 206-214. https://doi.org/10.1080/1360080X.2013.775929

Taylor, P., \& Braddock, R. (2007). International university ranking systems and the idea of university excellence. Journal of Higher Education Policy and Management, 29(3), 245-260. https://doi.org/10.1080/13600800701457855

Thakur, M. (2007). The Impact of Ranking Systems on Higher Education and Its Stakeholders. Journal of Institutional Research, 13(1), 83-96.

Usher, A., \& Medow, J. (2009). A Global Survey of Univesity Rankings and League Tables. In B. M. S. Kehm, Bjørn (Ed.), University Rankings, Diversity, and the New Landscape of Higher Education. The Netherlands: Sense Publisher.

Usher, A., \& Savino, M. (2006). A World of Difference: A Global Survey of University League Tables. Toronto: Educational Policy Institute.

Usher, A., \& Savino, M. (2007). A Global Survey of University Ranking and League Tables. Higher Education in Europe, 32(1), 5-15. https://doi.org/10.1080/03797720701618831

Van Vught, F. (2008). Mission Diversity and Reputation in Higher Education. Higher Education Policy, 21(2), 151-174. https://doi.org/10.1057/hep.2008.5

Xavier, C. A., \& Alsagoff, L. (2013). Constructing "world-class" as "global:" a case study of the National University of Singapore. Educational Research for Policy and Practice. https://doi.org/10.1007/s10671-012-9139-8

Yonezawa, Akiyoshi. (2011) The "Global 30" and the Consequences of Selecting 'World-Class Universities' in Japan. Paths to a World-Class University Lessons from Practices and Experiences. (Liu, N. C. W., Qi \& Cheng, Ying. Eds) The Netherlands: Sense Publishers.

\section{Note}

Note 1. Current Times Higher Education World University Rankings. The study referred to the previous version Times Higher Education Supplement as it was submitted in November 2009. 